\title{
ANC's step-aside rule through the eye of the missio politica as mandated by Missio Dei
}

\author{
Jonas Sello Thinane \\ Humanities Faculty \\ University of the Free State, \\ South Africa \\ E-mail: jsthinane@gmail.com \\ Orcid i.d: https://orcid.org/0000-0002-8522-8519 \\ Doi:
}

'You can't sit home, Johannes, and do nothing. Our people are fighting for freedom.

They need our support' - (Reimer, 2017:1.2)

\begin{abstract}
The broader practice of politics in the world, while detached from the religion, cannot be excluded from the mission of the Missio Dei. In fact, the question of mission and politics has prompted Professor Johannes Reimer to propose missio politica as a missiological framework that puts the mandate of mission and politics in one basket. Following this solid foundation, this paper will propose the use of missio politica as an important missiological framework to analyse the instrumentally useful politics in line with the ultimate goal of Missio Dei. In accordance with the tenets of both missio politica in the name of missio Dei, this paper will then consider the South African ANC's step-aside rule from a biblical perspective, arguing that the accounts of Samuel's leadership in 1 Samuel 8 and the story of Ananias with his wife in Acts 5:1-11 represent a somewhat biblical understanding of the step-aside rule. The ANC's step-aside rule only serves to relativize the need for a missio politica. This paper promises a better understanding of the relationship between mission and politics, such an understanding is a key to uncovering new ways to ensure a meaningful participation of all other sectors of society in achieving the goal of Missio Dei. Missio politica represent what has been missing in the missiological discourse. Therefore, this framework needs to be further explored in order to emphasize the mandate of politics in accordance with the Missio Dei.
\end{abstract}

Keywords: Missio Dei, missio politica, politics, Step-aside, African National Congress

\section{Introduction}

Despite the fact that Professor Johannes Reimer (born 28 January 1955) eventually became Professor of Missiology at the University of South Africa (UNISA) from 1995, he grew up an atheist and spent much of his youth in the political arenas of the Soviet Union as one of the leaders of the communist youth association. He later converted to Christianity and first began studying theology at the Wiedenest Bible School (1976-1979), the Theological Seminary Hamburg-Horn (1981-1983), the Mennonite Brethren Biblical Seminary (1983-1985) and UNISA (1990-1994). In particular, while studying at UNISA, he became a student of outstanding missiology professors such as Professor David J. Bosch (1929-1992) and Professor Willem A. Saayman (1942-2015). And it was precisely at this institution that he received his doctorate in theology (Reimer, 2017:1.3). Therefore, his experience in both politics and missiology is undoubtedly exceptional and qualifies him as a knowledgeable professor in both arenas. With the background and guidance of the missiologist mentioned above, including the influence of the American theologian Professor Johan Howard Yoder 
(1927-1997), Professor Reimer was able to publish an excellent book in 2017 entitled: 'Missio Politica: the mission of Church and Politics', in der he examines the integral connection between mission and politics. According to his understanding, both mission and politics shares responsibility or priorities of human needs.

Following the foundations laid by Professor Reimer, this paper intends to do a few things: First, it will present the political context that led to the International Mission Conference (IMC) in Willingen in 1952, in order to provide the missiological basis inviting mission-political analysis. Second, the concept of Missio Dei is examined from the perspective of the 1952 Willingen Conference, which expanded the question of mission beyond the confines of the Church, including new perspectives that dominated mission beyond Willingen. Thirdly, an attempt is made to define the concept of politics as being another institution that can be used in the work to achieve the goal of the Missio Dei, or as another important strategic component to be used in the work of the Missio Dei. Fourth, proponents of missio politica are identified as stemming from ecumenical engagements of the IMC and the Churches Commission on Internal Affairs (CCIA) that arose through the merger initiated in 1961 by the IMC and the World Council of Churches (WCC). Eventually, the further developed concept of missio politica is then introduced as an important missiological framework from the perspective of Professor Johannes Reimer. Sixth, it introduced the mandate of the missio politica in the context of the missio Dei. Finally, it makes use of missio politica to examine the ANC's step-aside rule first from a biblical perspective and as a final point to justify it within the broader goal of missio Dei. This introduces the missio politica as an important missiological framework, first to align politics with the important objective of the Missio Dei, and second, as an important framework to define the criteria not only for the Christian religion but for all religions under the sun to analyse and discern the deepest political realities of her constituency.

\section{Political context towards Willingen}

The circumstances in which the International Missionary Conferences that preceded Willingen in 1952 witnessed their own political struggles, which naturally could have shaped the missiological views of those who attended such conferences. According to Bosch (1980), as correctly repeated in Botha (2005), the 1928 Jerusalem Conference took place in the political context resulting from the First World War of 1914-1918 and the Russian Revolution of 1917 (Bosch, 1980: 161; Botha, 2005:135). . As recited by Botha (2005), Ranson (1948) observed that the 1947 Whitbay Conference perceived the world as: 'a world in agony, a revolutionary world' (Ranson, 1948:185; Botha, 2005:143).

It has been noted by several scholars that the Willingen International Missionary Council (IMC) conference of 1952 on 5-21 July was convened in the aftermath of the Second World War (1939-1945) and the unpredictable political context in China (1945-1952) or what came to be characterized by the Chinese Revolution of 1949 whereby after the lengthy political conflict between the Nationalist government and the Communist Party (1945-1949) on 1 October 1949 the Chinese Communist leader, Mao Zedong (Mao Tse-tung) declared the official establishment of the People's Republic of China (PRC) (Andrews, 1985:29-35; Davis, 2000:251-271; Hung, 1991:85). This conflict, which was of a political nature, cut the flow of missionary activities almost to a standstill (Bosch, 1980:178-181; 2011:379; Botha, 2005:145146; Matthey, 2003:579). Speaking of the Brethren Missionaries who at the time worked at the Northern Province of China, called Shanxi between 1945 and 1952, in their excellent paper entitled: 'Bridging 1949: Brethren Missionaries and the Communist Revolution', - Vera, Bach, and Kenley (2013) felt that they (missionary brothers) somehow failed to realize that such a political conflict would ultimately make it impossible for them to stay in China or even continue their missionary work, especially after the communist forces had invaded and conquered their Liaozhou mission station in 1946 notwithstanding the Brethren's neutrality in the political conflict (Vera, Bach \& Kenley, 2013:153-155). This means that neutrality or being politically correct has never been sufficient to ensure salvation. In fact, Reimer (2017) testified that political dilemmas continued to haunt him, or his church colleagues in general, even after he 
had left political activity. He further lament that the political powers of the Soviet Union made his life miserable that he fled the country (Reimer, 2017:1.1). Although most missionaries sought ways to coexist with the communist state, the communist forces suspected most foreign missionaries of being hostile to them, competing ideologies or at most pro-nationalist (Tucker, 1976:98-100). In the years that followed, as communist forces conquered more and more cities, the future of Christianity, as embodied by all Christian missionaries, including but not limited to Methodist, Catholic, and Protestant missionaries in China, continued to look bleak, up until an extreme stage where several missionaries were either arrested, imprisoned or murdered by the communist forces (Botha, 2005: 145). All these came after several missionaries had enjoyed reasonably years if not decades of peaceful travel in and out of several mission-promising countries, including countries like China (Forster, 1952:27). According to Vera, Bach and Kenley (2013) and Tucker (1976) by at least July of 1949, most missionaries who remained in china despite these political challenges where under communist rule (Tucker, 1976:97-116; Vera, Bach \& Kenley, 2013:161). In fact, the Willingen Conference took place shortly after the Defiance campaign, which saw the oppressed people of South Africa take to the streets on June 26 of the same year to oppose the unjust laws of apartheid (Hirson, 1988:70-101; Vahed, 2013:68-89).

In general, the Willingen Conference broadly coincided with dramatic political processes that include the rapid decolonization of several Asian and African countries, occurring particularly between 1945 and 1960 but typically between 1930s and 1970s (Bogaerts \& Raben, 2012; Botha, 2005:145). However, in particular the situation in China seem to have sent out strong fears that a similar political crisis might be repeated in other places across the world, or at least in countries where missionary activities were still ongoing. In the words of Botha (2005): 'All these developments gave rise to an atmosphere of political uncertainty at the time of the Willingen conference' (Botha, 2005:145). As if to reconcile the Willingen conference's status quo with the political situation in China, Forster (1952) pointed out that, unlike during the few previous world conferences, the Chinese delegation was not present at the Willingen conference (Forster, 1952:27), while Paul Lehmann as correctly recited in Aagaard (1973) referred to the prevailing mood of the Willingen Conference and even asked: 'In a word, was there, or was there not, a direct line between evangelism and politics?', a question to which he subsequently replied by arguing that the main reason for the Willingen Theological Commission's long delay in accepting the report was simply: 'because the report undertook to explore a direct line between missions and history, between evangelism and politics' (Aagaard, 1973:22-23). Against this background, it is important to continue the task of defining politics in a way that takes account of the fact that the models and contexts of politics evolve over time. In other words, the current perception of politics in South Africa today differs significantly from the perception of politics under and before apartheid. Unlike pre-1994 politics, in which racist systems dictated politics, while there are still challenges that includes racial discrimination, current politics is essentially more of a concerted effort to correct past injustices, deepen democracy, and ensure better life for all.

\section{Willingen and Missio Dei}

The meeting of the International Missionary Council convened in 1952 at a small village called Willingen in Germany. On the one hand Willingen was the first village where the international conference of such great importance took place, on the other hand it became the source of the missionary revival. Emphasising further on the significance of this conference being held in Willingen, Forster (1952) alludes to a statement by a German pastor who lamented that the 1952 IMC meeting was the third important event to take place in Willingen, after the first event when St. Boniface preached the gospel there, and the second important event, which was when Martin Luther donated a copy of the Bible to the Willingen Church. Referring to Professor Freytag who later described the experience, Foster further quoted him as saying: 'It was a new experience to pass in the street cows and hay wagons when on the way to meetings' (Foster, 1952:26). 
As substantiated by Matthey (2003), it was under troubling political context that the Willingen conference had to fundamentally reconceptualise the understanding of mission in the time of uncertainty (Matthey, 2003:579). Although the conference was held under the theme "The Missionary Obligation of the Church" (Thinane, 2021b:6), the nature of the discussions aimed to decentralize missionary activities from the confines of the church. Although the early history of the Church was marked by a theology that attempted to confine salvation to the Church, it culminated in the Council of Florence in 1442, where it was proclaimed that there is no salvation outside of the Church \{Extra Ecclesiam Nulla Salus\} (Jankiewicz, 2017:78), Philip (1999) traces the problem of the church-centred view in relation to mission from as early as the 1910 Edinburgh conference to the 1938 Madras conference, which asserted that while the salvation of mankind is centred in God's work, that salvation is accomplished through the church (Philip, 1999).

The big question, not articulated in so many words in the conference papers, was why the Church had so dominated missionary plans in recent years that its role in mission was overestimated and the impression created that it was the anchor or the main actor of the mission and not the Triadic God. According to Botha (2005) the paper presented by Max Warren at the conference emphasised the understanding that places the triadic God as the starting point for a theology of mission and not the Church (Botha, 2005:145). Thinane (2021b) cited Philip (1999) who indicated that the Dutch Reformed Church minister, Johannes Christiaan Hoekendijk was among those who refused to define mission in a way that seeks to restrict its activities to the confines of the church (Philip, 1999; Thinane, 2021b:6). In the words of Bosch (2011): 'It (Willingen Conference) recognized that the church could be neither the starting point nor the goal of mission. God's salvific work precedes both church and mission' (Bosch, 2011:379). In other words: Willingen became an important step towards overcoming the church-centred understanding of mission that had always dominated the mission discussion. Above all, an important insight from Willingen is that all aspects of mission are rooted in the Missio Dei, hence it sought to embrace the Triadic God as the sole origin of all missionary endeavours under the sun. Thus, by the end of the conference, there was general agreement that while the Church's role in the Missio Dei should not be taken for granted or downplayed, its rightful role is that of an instrument in the mission of the Triadic God (Thinane, 2021b:7).

\section{Missio Dei Post-Willingen}

Immediately after Willingen, it became necessary to embrace the new understanding of the Missio Dei as the source of all other missions cantered around the Triadic God. In other words, From Willingen it became clear that the missionary path begins and ends with the Triadic God and not with the church. That is to say, while the Church remains an important participant in the work of the Missio Dei, the work of the Missio Dei itself is far greater than what the Church alone can cover. Bosch (2011) alluded to the next IMC meeting which happened in a Ghanaian town called Achimota in 1958, from which it was re-emphasised that mission belongs to the triadic God and not the church. He further states that shortly after the conference, the British missiologist, Lesslie Newbigin summarised the conference's consensus by reiterating this very understanding placing the triadic God at the very centre of mission while remains a participant of such mission (Bosch, 2011:379). This is confirmed by Thinane (2021b), who recites the words of Lesslie Newbigin, who tried to reemphasize Willingen's reasoning by stating that: 'The missionary movement of which we are a part has its source in the Triune God himself' (Thinane, 2021b:7). In other words, after Willingen it became important or necessary to broaden the understanding of the Missio Dei as an accommodating or overarching mission to all other mission participants, be they political, economic or religious. Consistent with this understanding, Reimer (2017) has written emphatically: 'mission must therefore always include all creation not just parts of it' (Reimer, 2017:2.4).

The term Missio Dei was coined by the former Director of the Basel Mission, Professor Karl Hartenstein in his article on the Willingen Conference. As recited in Aagaard (1973) he wrote: 
Mission is not only the conversion of individuals, it is not only obedience to a world of the Lord, it is not only the obligation to gather the congregation; it is participation in the sending of the Son, the missio Dei, with the all-embracing aim of establishing the Lordship of Christ (Aagaard, 1973:12).

The work of Karl Hartenstein was then later followed by the 1958 German book of Professor Georg Vicedom entitled: 'Missio Dei' and seven years later was translated into English entitled: 'The mission of God: an introduction to a theology of misison' wherein the concept of Missio Dei was further reinforced (McPhee, 2001:7; Thinane, 2021b:8). In fact, as recited in Aagaard (1973) the new Willingen understanding of Missio Dei as validated by the 1962 ecumenical study on 'The Missionary Structure of the Congregation' (Margull 1963:433-446), as summarized by the Norwegian missionary, Bishop Fridtjov Birkeli (1906-1983) reiterated unambiguously that:

Mission is not the mission of the Church, because mission is a predicate of God. God is a missionary God... Missio Dei is active in the whole of history; it means that God turns to the whole world both inside and outside the Church. Through the events of history God guides the world (Aagaard, 1973:13)

This observations is further reinforced by the 1968 Uppsala conference, equally reaffirming that all these missionary efforts, including but not limited to the Missio ecclesiae, are only temporary ways of showing obedience to the call of the Missio Dei (Aagaard, 1973:11-13). It is upon such rich and multifarious understanding of Missio Dei from the perspective of Willingen that this paper will seek to include missio politica as yet another integral part of the scope of Missio Dei.

\section{Politics in - Missio Dei}

Before attempting to define what politics is or what it is about, it is important to reiterate that this paper is only interested in politics in the context of Missio Dei, or in defining politics in line with Missio Dei. Although the following section relies on the available literature to define the term politics, it does so with the firm intention of reconciling such definitions with the mission of the Missio Dei.

The term 'politics' is derived from the Greek word ' $П$ so the term Поגıтıкó would broadly refer to the affairs or activities of the cities. However, apart from its linguistic etymology, politics is evidently a loaded term that has a wide variety of meanings when defined by different people for different contexts. Following the example of the two theologians John Stott and Willem A. Saayman, Reimer (2017) defined politics on the one hand as the art of living together in society and on the other hand as the art of governing human affairs in relation to life as a whole (Reimer, 2017:3.1). The term politics does not have a clear or uniform meaning, but can be defined differently by different people for different reasons. Although there is no single way to reconcile all existing definitions of politics, scholars such as Alexander (2014) and Stein (2018) accepted this ongoing difficulty in unifying all existing definitions of politics but then suggested that such definitions can serve a broader purpose if they are grouped in a way that shows some coherence of application (Alexander, 2014:273; Stein, 2018:9). Examples of such diverse but easily 'groupable' definitions include: administration of public affairs, enforcement of social values, seeking conflict resolution, governance, ordering of a society, exercise of power or authority, collective decision-making, allocation of public funds, etc. As if seeking ways to reconcile the Genesis 1:26 creation account with the definition of politics that seeks to order society, Reimer (2017) speaks of a cultural mandate by which human beings are expected to cultivate land, develop music and build cities for the betterment of all (Reimer, 2017:2.3). These definitions can be condensed into two forms of definitions: the narrow definition of politics and the broad definition of politics. The narrower definition speaks of politics as an exclusive social space for politicians, while 
the broader definition speaks of politics as an inclusive space for members of a particular society.

Against the above stated background, this paper is only interested in the broader definition of politics, which encompasses the broader range of human activities in a society. Perhaps one such definition is provided by the Classical period's Greek philosopher and founding father of politica science, Aristotle (384-322 BC) described man as an inherently political being

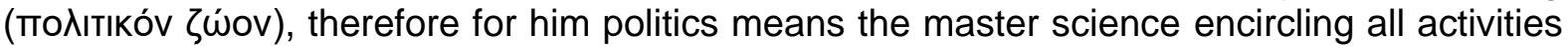
through which human society seeks to improve its life, to find happiness (Eủסaınovía) and to create the good ordered society (Depew, 2009:399; Mulgan, 1974:438). In fact, Reimer (2017) seems to go even further, arguing that since human beings are created to rule the world, their vocation in God's mission is inherently political. Finally he explained: 'God's first mandate for humankind is political in nature, and this mandate has never been taken back from humans, not even after the fall of man in the Garden of Eden' (Reimer, 2017:3.1)

From Willingness perspective, as indicated above, the basic understanding of mission expanded and even opened the door to several approaches to mission. In other words, from the time of the Willingen Conference it became clear that God's mission extends beyond the institutional framework of the church into all areas of life including politics, which is why Matthey (2003) would comment that: 'Missio Dei also helped to open up the realms of politics and economics so that they became an integral part of the mission agenda' (Matthey 2003:580). Thus, if at all the perceived relevance or pros and cons of the doctrine of the separation of religion and politics (Ferrara, 2009:77-91; Walzer, 1998:295-307) or church and state (Audi 1989:259-296; Witte 2006:15-45) predates 1952, then the importance of the Willingen Conference or its perspectives has outweighed that relevance since it has successfully emphasized without a reasonable doubt that the mission of God or the Missio Dei takes place beyond the institutional boundaries that the Church has always retained. Also, such separation was only relevant at the time when the definition or concept of politics was described only on the basis of the concept of the state or the state only on the basis of the concept of politics (Alexander, 2014:273). Thus the relevance of such narrow definition falls on the progressive sword of the Missio Dei, particularly from the Willingen perspective on the one hand and on the progressive sword of new and broader understanding of what politics mean. Therefore it becomes fundamentally important to search or generate new insights that take into account the Missio Dei's recent understanding of the world and new insight into the question of politics within societies. The doctrine of the separation of religion and politics, or church and state, so to speak, could perhaps be factored in or be linked with Aagaard's (1973) thinking when he alludes to the old fixed horizons that are being broken down (Aagaard, 1973:15).

On condition that that the fundamental right to freedom of religion is not in any way interpreted in such a way that it contradicts the right to political participation, freedom of religion can certainly also be interpreted in a ways that gives adequate recognition to missio politica, i.e. interpretation that embraces political analysis from the perspective of the Missio Dei. Religious freedom in this sense would mean that believing citizens are equally free to interpret politics in accordance with their religious teachings. Similarly, Walzer (1998) puts it: 'So it is very important that people whose views have had a religious formation learn to politicize them. They don't need to leave them behind when they enter the arena' (Walzer, 1998:2978). Stereotypically, similar conduct is more demonstrated by religious organizations, especially the Christian religion. Incidentally, Reimer (2017) testifies to this in his introduction, where he explains how he first became involved in politics before becoming a Christian, and how his pastor urged him out of such political activities, arguing that politics is a dirty business. Unfortunately, as it could be expected, his departure from politics resulted in the loss of his non-Christian friends. In other words, encountering Christ came at the high price of losing friends to him (Reimer, 2017: 1.1). More than anything, this shows the way in which society itself has irrationally erected impenetrable walls between two social institutions as if they did not fall under one sky. In one way or another, both politics and religion remain subject to the 
work of Missio Dei, which is why missio politica is more interested in political commitments that are only relatively or instrumentally useful in achieving Missio Dei's ultimate goal.

\section{Proponents of Missio Politica}

In its broader form, the concept of Missio Politica was initially developed from ecumenical engagements of the International Missionary Council (IMC) and the Churches Commission on Internal Affairs (CCIA) as a result of the merger of the IMC and World Council of Churches (WCC) in 1961 (Reimer, 2017:1.4). The work of these engagements is comprised in Teinonen (1961) book entitled: 'Missio politica oecumenica : a contribution to the study of the theology of ecumenical work in international politics'. Following these efforts, much of the earlier work on the concept of missio politica oecumenical was then developed by the Dutch missiologist, Johannes Verkuyl (1908-2001) in his 1976 book entitled: 'Inleiding in de nieuwere Zendingswetenschap'. Also, adding to this was the excellent work of Professor Willem Saayman on his 1997 book entitled: 'Christian Mission in South Africa' with its chapter one solemnly dedicated towards the topic of Mission, politics and ecumene.

The most recent understanding of missio politica can largely be attributed to the 2017 excellent work of the Russian-German professor of missiology, Professor Johannes Reimer entitled 'Missio politica: the mission of church and politics', followed by its 2021 German version entitled: 'Die politische Mission der Kirche wie wir teilhaben an Gottes Wirken in der Welt' as the most recent missiologist to address the question of politics from the perspective of the Missio Dei. In fact, the latest German title as it could be roughly translated into: 'The political mission of the church as we participate in God's work in the world' is more descriptive and reflects the correct understanding of the Missio Dei from the perspective of the Willingen Conference of 1952, which saw the Church's mission as mere participation in the wider work of the Missio Dei. Although not adequately acknowledged, his excellent work on this concept is plausible and commendable, since without his excellent contribution, work such as the present work would certainly not be possible.

\section{Missio Politica and Missio Dei}

Although it is expected that some missiologists or theologians in general might be inclined to question, accuse or label missio politica of being some kind of a secular theology that is somehow obsessed with ignoring the primary role of the church in the eternal work of Missio Dei. As on the contrary, Reimer (2017) explained that while Professor Bosch had his own agitation with the question of church and politics, he encouraged him to continue his pioneering research reconnecting mission with its political component, even if it means drawing hazardous criticism (Reimer, 2017:1.4). As if he wanted to rebuke such tendencies, Aagaard (1973) stated that: "The tendency to label this whole trend towards a theology relevant for the present world as secular theology is superficial and irresponsible' (Aagaard, 1973:10).

The assertion that the Church alone is the main actor of Missio Dei is not only absurd, but also backward and incompatible with Willingen's understanding of Missio Dei. Furthermore, it is unthinkable that the Triadic God would choose the Church as the exclusive participant in the Missio Dei, to the While it may be important to be extra cautious when it comes to involving the Church in politics, it cannot be the same when it comes to how the Triadic God chooses to use politics to achieve the ultimate goal of Missio Dei. Although the connection between God and politics might encounter myriad theological problems for human understanding, politics cannot be too far from God's reach, especially when it comes to His divine plan of achieving the ultimate goal of the Missio Dei. In the absence of a better wording, it can be stated that the Missio politica seeks the reintegration of political human action into the allencompassing Kingdom of God from the point of view of the Missio Dei. In other words, missio politica is about political processes that correspond to or respond to the call and ultimate goal of Missio Dei. Therefore, It is somewhat troubling to note that decades after Willingen's revised understanding of Missio Dei or what Bosch (2011) correctly refers to as: 'a momentous shift 
in the understanding of church and mission' (Bosch, 2011:380), new missiological frameworks such as missio politica have not received adequate recognition, despite the apparent reality that the appropriate application of missiology is in one way or another at a crossroads with politics. Indeed, this is consistent with Aagaard's (1973) analysis, which points to the important role played by Paul Lehmann in examining the political context of the Willingen Conference, thereby reinforcing the often-overlooked argument that most, if not all, of the important premises of the Political theology is rooted in missiological thinking (Aagaard, 1973:23). Perhaps that is what Professor Saayman meant when he told Professor Reimer that missionary work is inherently political. In fact, this also echoed the view of Professor Johannes Verkuyl, who argued that the mere declaration of Yahweh as God and Jesus as Lord is a creed but at the same time deeply political (Reimer, 2017:1.3). In his own book, Saayman (1997) referred to what Peter said at Acts 2:22-24; 3:13-16 and also the situation where Peter and John boldly instigated civil disobedience in the name of speaking the truth at Acts 4:1820; 4:23-31 may have been political in nature (Saayman, 1997:1). It is therefore not surprising that Professor Reimer affectionately attributes the contents of his book to Professor Saayman, saying: 'Some of what I have learned from my beloved late professor is presented on the pages of this book' (Reimer, 2017:1.3).

\section{Biblical notion of step-aside}

Complex as it is, in this section we attempt to emphasize the biblical perspective of the stepaside idea. This is usually a complex issue as there are not as many biblical instances where a leader is asked to voluntarily resign or be temporarily suspended to allow an accountability process to clear their name of alleged wrongdoing as is the case with the African National Congress (ANC) Policy. However, this is accomplished by highlighting several biblical instances where a leader has had to step-aside from their positions of leadership simply because their conduct or moral compass is contrary to efforts aimed at achieving the goal of the Missio Dei, or better yet, if it is observable that their continued leadership will do more harm than good to Missio Dei's efforts. The core idea is to carry through the efforts of achieving the goal of Missio Dei without being hampered by the misconduct of the leaders.

Much can be learned from both Old and New Testament scriptures about specific principles that the notion of stepping aside seeks to uphold in human society in general, and in particular its application to real situations such as political contexts. Reimer (2017) endeavoured to place God's presence in the midst of real life circumstances, stating: 'God's mission happens in time and space; it takes place in the world. He reveals himself in the midst of real life, and there are no parts of life he is not interested in' (Reimer, 2017:2.4). The Bible is full of stories of leaders, who may have been servants or participants in the Missio Dei, who sought to ensure the salvation of a particular society as mandated by the Missio Dei. Regardless of their positions, whether in government, politics, military, royalty, or religion, these leaders or their behaviour have always been subject to moral scrutiny in one way or another. They almost always had to behave in such a way that they were too careful not to draw the social attention to their own interests. In fact, the Bible often uses terms such as sincerity, righteousness, honourable, blameless, virtuous, and many other terms intended-for lack of better wordsto emphasize the spotlessness and immaculateness that must characterize such an important role in a society, especially since such a role was intended to advance the mandate of the Missio Dei.

\section{Samuel and Step-aside rule}

Reimer (2017) suggested that whoever interested in theology of mission must locate it from the Old Testament accounts since it speaks to the roots of God's plans with his own creation. He further states that: 'The Old Testament bears witness to God's salvific engagement in the world'....'The Old Testament lays foundations and formulates a frame of reference for a theology and praxis of mission in which all the main elements of God's mission are presented' (Reimer, 2017:2.2, 2.4, 2.8). In essence, this means that whatever God's purpose or plans for 
politics are in his own mission, they can be reconstructed from Old Testament stories. In terms of the Old Testament leadership stories, perhaps a complex yet simple example of the step aside rule can be derived from the situation involving Samuel's leadership and the people of Israel (1 Samuel 8). Although this event is meant to signify the transition from prophetic tradition to the new monarchical kingship, or a new political order as it were (Gamble, 2015:34; Michael, 2013:111), a closer reading reveals more consistency with the notion of the stepaside rule. Notwithstanding the supporting and conflicting arguments regarding Samuel's case, it is important to merely note that the Israelites had developed a somewhat unfavourable perception of his leadership, which ultimately led to his being asked to step-aside from his leadership role. Whatever the case, he was ultimately able to clear his name of any possible allegations made against him, and that's the point of the step-aside rule. While it can be argued that Samuel was innocent of all charges against him, his sons, whom he appointed judges of Israel, acted as their father's vicars and openly discredited his name by accepting bribes and perverting justice (1 Samuel 8: 3). In the immediate eyes of the people, the mere association of his name with his sons' contemptuous behaviour robbed Samuel of his credibility as a leader in a society, so they decided it was only right that Samuel and his sons step aside and let someone who was more credible is to lead them. It is possible that a delegation of the elders of Israel, after carefully examining all the facts before them, were firmly convinced that they had solid grounds for confronting Samuel about the wrongdoing that has stained his name, and on that basis alone came to the conclusion that Samuel had to step-aside. In other words, at the time when they confronted him, they had established a reasonable apprehension of misconduct, as supported by the facts in their possession, and this was overwhelming evidence that Samuel, on his part, had lost credibility to continue in a leadership role. Whether or not that decision was correct is not important here or there for the purpose of this paper, but what is important is the fact that Samuel's name has fallen into disrepute and this has led to people asking him to step-aside.

At the end of his service, Samuel is able to reflect on his leadership while clearing his name of all allegations of wrongdoing by prodding them with compelling questions. He asked the Israelites: 'Whose ox have I taken? Or whose donkey have I taken? Or whom have I defrauded or oppressed? Or from whose hand have I taken a bribe to blind my eyes with it?' to this testing questions, the Israelites answered by confirming that indeed Samuel has never defrauded or oppressed anyone throughout his tenure (1 Samuel 12:3). In principle, it can be argued that such a test is exactly what the step-aside rule is intended to achieve. The goal is to reach a stage where anyone confronted with serious allegations of wrongdoing can ultimately be either acquitted or found guilty. As demonstrated in 1 Samuel 12, Samuel finally walks away with a clear reputation, regardless of whether he has resumed his duties or not. More importantly, he stepped aside to allow the mandate of the Missio Dei to be borne by someone else while at the same time submitting to the process of purifying his reputation. The next important question to answer is: What then happens to a leader or member who is found nefarious or corrupt on the side of righteousness? Then the next cautionary account involving Ananias and his wife Sapphira is a case in point.

\section{Ananias and Sapphira}

Referring to the New Testament leadership stories, perhaps among the few examples of the ultimate intention of the step-aside rule can be derived from the cautionary account involving the behaviour of Ananias and Sapphira, his wife (Acts 5:1-11). Much like the notion of politics, which involves the exercise of both local and national power to ensure an equitable distribution of goods and services for the benefit of society (Herbst, 2001:1-6), As underscored in Acts 4:32-37, the early Christian believers, through the leadership of the apostles, had agreed to share their goods for their common good, entrusting the apostles, as it were, with the redistribution of the resources they had collected. One can argue that by virtue of them agreeing collectively on how resources are to be shared within or to the benefit of a group was in itself a political process. In view of this, a Levite named Joseph, whom the apostles called Barnabas, is presented here as an example of a virtuous man who sold his field and gave the 
money raised to the apostles without being dishonest or taking anything for himself (Acts 4:3637). However, just to the contrary, the man named Ananias with the consent of his wife Sapphira, sold their property but kept some money for themselves and gave just part of it to the apostles (Acts 5:1-2). Their dishonesty led to the apostle Peter rebuking them, he first had to question them about their purported wrongdoing to be sure before accusing them of lying to God (Acts 5:4-9), after which they in turn died on the spot (Acts 5:5-11). The question of whether their instantaneous death was literal or metaphorical, whether such punishment was appropriate or beyond their wrongdoing, is not important for the purposes of this paper, but what is important is the fact that their dishonesty in self-appropriating, what was intended for community use justified their immediate demise. If this new community (Ecclesiae) is to be considered at all the salt and light of the earth in the sense of Matthew 5:13-16 or as Reimer (2017) would refer to it: 'a model of a nation according to God's will and heart' (Reimer, 2017:2.6), then every member of such a community who has strayed on the side of righteousness, must be found guilty of utterly violating or blatantly flouting the oath of the institution to which they profess trustworthiness, and consequently should be declared defective and corrupt on the face of the intended aims of such a community, as did Ananias and his wife, who eventually received a punitive miracle or were excommunicated. As if allowing space for parallels to be made between the story of Ananias and most ANC members holding public office, Donne (2013) repeated the view of J. Albert Harrill, who suggested the conclusion that the couple had taken an oath which essentially committed them to righteousness (Donne, 2013:346-347). If such an oath is broken, the only appropriate punishment is expulsion as if such a person had died.

\section{ANC's Step-aside policy}

The subject of political party models has been extensively explored in literature by multiples scholars (Hibbs, 1977; Levy, 2004; Shefter, 1994). In a democratic country like South Africa, political parties are viewed as social arrangements through which citizens organize themselves to compete freely in the country's democratic elections (Piombo, 2005:447-470). Such democratic elections provide an opportunity for ordinary citizens to participate in the work of consolidating democracy by electing into political authority those political parties that reflect their hopes and aspirations (Lodge \& Sheidegger 2006; Pottie 2001; Randall \& Svasand 2002). In South Africa, the African National Congress (ANC) has enjoyed such political power since the first democratic elections in 1994 following the repeal of apartheid law on 17 June 1991 (Lodge, 2004; Letsholo, 2005; Southall, 2014; Twala, 2014). As the ruling political party, for years the ANC has understood that it exist within the public consciousness and it continually seeks to align itself with the public good. However, in recent years its governance has been marked by corruption committed by its members (Chipkin, 2013; Hyslop, 2005; Lannegren \& Ito, 2017). Although the State Capture Inquiry (or The Judicial Commission of Inquiry into Allegations of State Capture 2018-2022) was never specifically intended to try ANC members, its findings fingered some of its top leaders with serious allegations of fraud and corruption in both cases involving the public sector and State-Owned Enterprises (SOE) (Zondo, 2022a\&b). To rid itself of such characterization, years before the State Capture Commission was established, the ANC had begun to devise mechanisms aimed at rooting out corruption within its ranks (Bruce, 2014; Dintwe, 2012). The step-aside rule is one such mechanism functioning as the ANC's Integrity Framework to cleanse itself of tainted and corrupt leaders.

the ANC's step-aside resolution adopted or passed at its 54th National Conference in 2017 held at Nasrec under theme: 'Fighting crime and corruption', The ANC reiterated the resolution adopted at its National General Council (NGC) in 2015, ordering that those of its members who are implicated in moral wrongdoing or corrupt activities should either step-aside voluntarily or be removed until such a time their names are acquitted from such allegations (ANC 54th NC 2017:76). According to Thinane (2021a), this mechanism is primarily intended to encourage ANC members accused of corruption to either voluntarily resign from their public office within 30 days or to subsequently undergo an internal integrity process that will remove 
them from those positions until such a time their names are vindicated (Thinane, 2021a:1-15). During such a period of suspension, the relevant law authorities will seek accountability of allegations from the alleged member. In so many words, Rule 25.70 of the ANC Constitution states:

\begin{abstract}
Where a public representative, office-bearer or member has been indicted to appear in a court of law on any charge, the secretary general or provincial secretary, acting on the authority of the NEC [National Executive Committee], the NWC [national working committee], the PEC [provincial executive committee] or the PWC [provincial working committee], if satisfied that the temporary suspension of such public representative, office-bearer or member would be in the best interest of the Organisation, may suspend such public representative, elected office-bearer or member and impose terms and conditions to regulate their participation and conduct during the suspension (ANC Constitution, 2017:28).
\end{abstract}

Implementation of this land-marking rule came on March 30, 2021, when the ANC NEC gave its members, who were facing criminal charges, a non-negotiable 30-day ultimatum to either step-aside or be suspended. Among those members was then-ANC Secretary-General Elias (Ace) Sekgobelo Magashule, who, in his previous capacity as Premier of the Free State province, was formally charged with fraud, corruption and money laundering in connection with irregular R255 million asbestos contracts. After his failure to voluntarily step-aside, on 03 May 2021 the ANC Deputy Secretary-General Jessie Duarte informed him that he was temporarily suspended pending his criminal cases (Nicolson, 2021). In response, Magashule said his suspension was a fatal mistake and in return took it upon himself to suspend ANC President Cyril Matamela Ramaphosa on the basis that there were mere allegations of his involvement in corruption (Thinane, 2021a:9-10). Further details on how this rule was implemented or interpreted by different people in South Africa are beyond the scope of this paper, but what is important is to measure its usefulness in line with the achievement of the objective of Missio Dei, as the next section will seek to demonstrate.

\title{
ANC's step-aside and Missio Dei
}

This policy can be associated with Missio Dei as it seeks to counteract tendencies that are contrary to Missio Dei's ultimate aim or goal of total salvation which can be achieved through the Just kingdom of God. While reconciling the mandate of politics with the ultimate aim of Missio Dei, Reimer (2017) pointed out that salvation is central to God's mission and further stated that: 'The aim of all missionary energy flowing from God's heart seems to culminate in the salvation for all people' (Reimer, 2017:2.5). According to Philip (1999), the Kingdom of God became the broader theme that marked missionary conferences that came after Willingen, such conferences included but not limited to the Melbourne Conference of 1980 organized by the World Council of Churches (WCC) under the theme: 'Your kingdom Come', and the San Antonio Conference of 1989 under the theme: 'Your will be Done - Mission in Christ's Way' (Philip 1999). In other words, in line with the Willingen perspective of mission, the focus was no longer on church-centred mission, but on mission from the perspective of the kingdom of God in its entirety. Reimer (2017) referred to Saayman (1997) who upon arguing that the Church's mission is by nature bound with the political project of ordering the society, he also stressed that justice is central to the mission of the church and even almost similarly stated that in the absence of the Just Kingdom of God there is simply no salvation (Reimer, 2017:1.3; Saayman, 1997:12). In fact, it is such ethical efforts, as shown by advocates of this policy, that make the theological task of searching for a new understanding of salvation appear more urgent than ever.

The Missio Dei as embodied in the life of Jesus Christ showed how far the Triadic God is willing to go just to support or show solidarity with the suffering masses of the world. If this ANC policy is poverty-oriented at all, then it is difficult not to count it among the efforts of Missio Dei to bring about its goal of salvation to poor and ordinary South African masses. This no 
doubt agrees very well with the view of Professor Yoder, who argued that it is not possible to separate the teachings of Jesus Christ from politics (Reimer, 2017:1.3). Policies such as these, demonstrates the grace of the triadic God to the poor mases of the world even far more than the church can. In fact, Aagaard (1973) referred to the Willingens Conference report, which unequivocally stated that:

\begin{abstract}
The Church in carrying out its mission is required to identify itself with the world not only in its constant sin and tragedy but also in the moments when the world acts in accordance with the grace of God more effectively than the churches themselves (Aagaard, 1973:23).
\end{abstract}

In this aspect of the Missio Dei, South Africans, in their suffering, seem to have encountered the Triadic God attempting to oppose those unable to carry out a political mission or missio politica as prescribed by the Missio Dei. Indeed, the desperate reality that ordinary South Africans endure as they are ruthlessly exploited by individuals who hold positions of power regardless of their shortcomings is one more reason why the mandate of the Missio Dei needs to be expressed strongly through missio politica as yet another missiological framework striving to realize the goal of the Missio Dei. It is hard to imagine that the Triadic God, or the scope of his mission, would ever reject a policy embracing such ethical principles to reform societies or countries like South Africa to become ideal societies consistent with the ultimate aim of the Missio Dei. In fact, Reimer (2017) demonstrated God's influence in constituting societies by stating that: 'With great detail and interest in life, he offers Israel laws covering their social, economic, political and spiritual life (Reimer, 2017:2.4). Policies such as these are inadvertently intended to restore hope not only in an ethical society, but in a society that continues to strive towards the goal of Missio Dei. One can reasonably surmise that it is cases like these that Matthey (2003) wished to refer to when speaking of the unknown side of the triadic God or aspects of God's mission which, of course, might involve unexpected results superseding human prudence. After all, what are humans to comprehend God's missional plans in their entirety? (Matthey, 2003:581- 852). As though seeking to validate this unpredictable character of the triadic God in mission by citing Hans Kung's 1964 address at the Eucharistic Congress in Bombay, Aagaard (1973) re-emphasised that God's action towards the world is the same as towards the church. He further stated that: 'In the incarnation God was not bound to specific places or specific times, and he did not bind himself to act in one way in the Church and in another in the world' (Aagaard, 1973:19).

\title{
Conclusion
}

Although this paper attempted to invite a serious recognition of the missio politica as one of the important missiological frameworks of the missio Dei, it merely examined the ANC's stepaside rule regarding the mandate of the missio politica, inspired by the correct understanding of the Willingen's Missio Dei. Well beyond the work of this paper, missiologists around the world, and particularly in South Africa, have long engaged in discussing politics without using a formal missiological framework such as missio politica. That alone is one more reason why missio politica should be recognized as an important missiological framework encompassing the analysis of politics in view of the goal of Missio Dei. If at all the current political generation in South Africa has some anti-religious or especially anti-Christian component in their political ideologies so much that they no longer see any logic or relevance of religion, then that is all the more reason why missiological frameworks like missio politica should be deployed to underline pro-Missio Dei political policies and even to explore other avenues to encourage political constructive efforts aimed at achieving the goal of Missio Dei. Thus, the greater problem that arises from missiological muteness on politics is that theologians, particularly missiologists, are becoming complacent about an injustice being done to the people of South Africa, the very people who are the Christian constituency.

Effectively and systematically, this paper accomplished three things: First, it introduced the political contexts that shaped the concept of Missio Dei as understood by the IMC Willingen Conference in 1952, and used that understanding to build on the foundation laid by Professor 
Johannes Reimer, who proposed the recognition of missio politica as a missiological framework encompassing political matters related to Missio Dei. Second, it used the missio politica to analyze the ANC's policies on the side of the step from a biblical perspective and in line with the aim of the Missio Dei. Finally, it largely advocated for a serious consideration of the Missio Politica as an important missiological framework for analysing politics in relation to the broader context of achieving the goal of the Missio Dei.

\section{Reference list}

Aagaard, J. (1973). Trends in missiological thinking during the sixties. International Review of Mission, 62(245), 8-25

Alexander, J. (2014). Notes Towards A Definition of Politics. Philosophy, 89(2), 273-300.

ANC 54 th NC. (2017). ANC 54th National Conference: report and resolutions. [Online] Library Catalog (Blacklight). Johannesburg: African National Conference. Available at: https://searchworks.stanford.edu/view/13339660 [Accessed 30 Jan. 2022].

ANC, Constitution (2017). African National Congress constitution as amended and adopted by the 54nd National conference, Nasrec, Johannesburg 2017. https://www.anc1912.org.za/wp-content/uploads/2021/01/ANC-Constitution-2017.pdf

[Accessed 17 Feb. 2022].

Andrews, E.M. (1985). Australia and China, 1949: The Failure to Recognise the PRC. The Australian Journal of Chinese Affairs, (13), 29-50

Audi, R. (1989). The Separation of Church and State and the Obligations of Citizenship. Philosophy \& Public Affairs, 18(3), 259-296.

Bogaerts, E. and Raben, R. (2012). Beyond Empire and Nation; The Decolonization of African and Asian societies, 1930s-1960s. Kitlv Press

Bosch, D.J. (1980). Witness to the world: the Christian mission in theological perspective. Atlanta: John Knox

Botha, N. (2005). From Edinburgh to achimota: the world mission conferences as a source of missiological knowledge in the thinking of D J Bosch. Studia Historiae Ecclesiaticae, 31(2), 129-152

Bruce, D. (2014). Control, discipline and punish?: Addressing corruption in South Africa. South African Crime Quarterly, 48(1), 49-62

Chipkin, I. (2013). Whither the State? Corruption, Institutions and State-Building in South Africa. Politikon, 40(2), 211-231

Davis, D.S. (2000). Social Class Transformation in Urban China. Modern China, 26(3), 251275.

Depew, D. (2009). The Ethics of Aristotle's Politics. In: R. Balot, ed., A companion to Greek and Roman Political Thought. USA: John Wiley \& Sons.

Dintwe, S. (2012). The African National Congress Led Government's (In)ability to Counter Public Corruption: A Forensic Criminological Perspective. Africa's Public Service Delivery and Performance Review, 1(2), 5-20

Ferrara, A. (2009). The separation of religion and politics in a post-secular society. Philosophy \& Social Criticism, 35(1-2), 77-91.

Foster, J. (1952). Willingen, 1952. The Expository Times, 64(1), 26-29 
Gamble, D.E. (2015). An exegetical study of the Masoretic notes and text of 1 Samuel 8. www.academia.edu. [online] Available at: https://www.academia.edu/14275386/AN_EXEGETICAL_STUDY_OF_THE_MASORETIC_ NOTES_AND_TEXT_OF_1_SAMUEL_8[Accessed 5 Feb. 2022].

Herbst, J. (2001). The politics of revenue sharing in resource-dependent states. [online] www.econstor.eu. Available at: http://hdl.handle.net/10419/52758.

Hibbs, D.A. (1977). Political Parties and Macroeconomic Policy. The American Political Science Review, 71(4), 1467-1487

Hirson, B. (1988). The Defiance Campaign, 1952: social struggle or party stratagem? 70 Searchlight South Africa, 1(I), 70-102

Hung, W. (1991). Tiananmen Square: A Political History of Monuments. Representations, (35), 84-117

Hyslop, J. (2005). Political Corruption: Before and After Apartheid. Journal of Southern African Studies, 31(4), 773-789

Jankiewicz, D. (2017). Martin Luther and Extra Ecclesiam Nulla Salus ("Outside of the Church There is No Salvation"): Did Luther Really Abandon Cyprian?. Journal of the Adventist Theological Society, 28(2). 78-96.

Lannegren, O. \& Ito, H. (2017). The End of the ANC Era: An Analysis of Corruption and Inequality in South Africa. Journal of Politics and Law, 10(4), 55-59

Le Donne, A. (2013). The Improper Temple Offering of Ananias and Sapphira. New Testament Studies, 59(3), 346-364.

Letsholo, S. (2005). How the ANC won the 2004 elections: perspectives on voting behaviour in South Africa. Aukland Park, South Africa: Eisa

Levy, G. (2004). A model of political parties. Journal of Economic Theory, 115(2), 250-277.

Lodge, T. (2004). The ANC and the development of party politics in modern South Africa. The Journal of Modern African Studies, 42(2), 189-219

Lodge, T. \& Sheidegger, U. (2006). Political parties and democratic governance in South Africa. Auckland Park: Electoral Institute of Southern Africa

Margull, H.J. (1963). Structures for missionary congregations. International Review of Mission, 52(208), 433-446

Matthey, J. (2003). God's mission today: summary and conclusions. International Review of Mission, 92(367), 579-587

McPhee, A. (2003). The missio Dei and the transformation of the church. Vision: A Journal for Church and Theology, [online] 4(1), 6-12.

Michael, M. (2013). Saul's Prophetic Representations. Old Testament Essays, 26, 111-136.

Mulgan, R.G. (1974). Aristotle's Doctrine That Man Is a Political Animal. Hermes, [online] 102(3), 438-445.

Philip, T.V. (1999). Edinburgh to Salvador: twentieth century ecumenical missiology: a historical study of the ecumenical discussions on mission. Delhi: Ispck.

Piombo, J. (2005). Political Parties, Social Demographics and the Decline of Ethnic Mobilization in South Africa, 1994-99. Party Politics, 11(4), 447-470 
Pottie, D. (2001). The Electoral System and Opposition Parties in South Africa. Democratization, 8(1), 25-52

Randall, V. \& Svåsand, L. (2002). Political Parties and Democratic Consolidation in Africa. Democratization, 9(3), 30-52

Ranson, C.W. (1948). Renewal and advance: Christian witness in a revolutionary world. London: Edinburg House

Reimer, J. (2017). Missio politica: the mission of church and politics. Carlisle, Cumbria: Langham Global Library.

Reimer, J. (2021). Die politische Mission der Kirche wie wir teilhaben an Gottes Wirken in der Welt. Holzgerlingen Scm R.Brockhaus.

Saayman, W.A. (1997). Christian mission in South Africa: political and ecumenical. Pretoria: Univ. Of South Africa.

Shefter, M. (1994). Political parties and the state: the American historical experience. Princeton N.J.: Princeton University Press

Southall, R. (2014). From liberation movement to party machine? The ANC in South Africa. Journal of Contemporary African Studies, 32(3), 331-348

Stein, M. (2018). What is the "Political" in Political Philosophy? Conference paper. [online] Available https://www.researchgate.net/publication/328887243 What is the \%27Political\%27 in Poli tical Philosophy [Accessed 4 Feb. 2022].

Teinonen, S.A. (1961). Missio politica oecumenica: a contribution to the study of the theology of ecumenical work in international politics. Helsinki: Suomen Lähetystieteellinen Seura.

The Missionary Structure of the Congregation. (1962). Occasional Bulletin from the Missionary Research Library, 13(8-9), 1-9.

Thinane, J.S. (2021a). Thuma Mina - an Isaiah 6:8 perspective in crossfire with Step-aside: SA ruling party's moral restoration efforts. Pharos Journal of Theology. 104(1), 1-15

Thinane, J.S. (2021b). Missio Dei as the Main Project: Project Management Model for Mission of God. Religion, ethics and communication in the era of the COVID-19 pandemic, (102(2)).

Tucker, N.B. (1976). An Unlikely Peace: American Missionaries and the Chinese Communists, 1948-1950. Pacific Historical Review, 45(1), 97-116

Twala, C. (2014). The African National Congress (ANC) and the Cadre Deployment Policy in the Postapartheid South Africa: A Product of Democratic Centralisation or a Recipe for a Constitutional Crisis? Journal of Social Sciences, 41(2), 159-165

Vahed, G. (2013). "Gagged and trussed rather securely by the law": The 1952 Defiance Campaign in Natal. Journal of Natal and Zulu History, 31(2), 68-89

Vera, C., Bach, J. and Kenley, D. (2013). Bridging 1949: Brethren Missionaries and the Communist Revolution. American Journal of Chinese Studies, 20(2), 153-165

Verkuyl, J. (1976). Inleiding in de nieuwere zendingswetenschap. Kampen: Kok.

Walzer, M. (1998). Drawing the Line: Religion and Politics. Soziale Welt, 49(3), 295-307.

Witte, J. (2006). Facts and Fictions About the History of Separation of Church and State. Journal of Church and State, 48(1), 15-45. 
Zondo, R. (2022a). Judicial Commission of Commission of Inquiry into Inquiry into State Capture State Capture Report: Part 1 Report: Part 1 Vol. 1: South African. [online] Available at: https://www.gov.za/sites/default/files/gcis_document/202201/judicial-commission-inquirystate-capture-reportpart-1.pdf [Accessed 17 Feb. 2022].

Zondo, R. (2022b). Judicial Commission of Inquiry into State Capture Report Part 2 VI | The Presidency. [online] Available at: https://www.thepresidency.gov.za/content/judicialcommission-inquiry-state-capture-report_part-2-vi [Accessed 17 Feb. 2022]. 